\title{
Efektivitas Larutan Mikroorganisme Lokal dari Tandan Kosong Kelapa Sawit Secara Aerob
}

\author{
Dermiyati ${ }^{(1) a}$, Anis Puji Andayani ${ }^{(2) b}$, Radix Suharjo ${ }^{(1) c}$, Ivayani ${ }^{(1) d}$, \\ Mareli Telaumbanua(3)e \\ (1) Dosen Jurusan Agroteknologi Fakultas Pertanian Universitas Lampung, Bandar Lampung \\ (2) Mahasiswa Jurusan Agroteknologi Fakultas Pertanian Universitas Lampung, Bandar Lampung \\ (3) Dosen Jurusan Teknik Pertanian Fakultas Pertanian Universitas Lampung, Bandar Lampung
}

email korespondensi: adermiyati.1963@fp.unila.ac.id, banispuji96@gmail.com,cradix_suharjo@yahoo.com, divayani.hpt@gmail.com, emarelitelaumbanua@gmail.com

\begin{abstract}
Planting area of oil palm plantations in Lampung Province is in the rank $13^{\text {th }}$ of Indonesia. Empty Oil Palm Bunches (EOPB) is an organic waste from fresh fruit bunches. The amount of EOPB is exceeded but it is not used optimally yet. This research aimed to study the effectiveness of the local microorganisms solution (MOL) of EOPB in aerobic condition, especially for bacterial population and and bacterial characteristics in EOPB MOL solutions. The observations were done by counting the number of bacterial population and bacterial characteristics were differentiated based on shape and color. In addition, other characteristics were also done in the form of grams' test, oxidative fermentative's test $(O / F)$ test, soft rot's test, hipovirulen's test, and hypersensitive. The results show that there were 84 isolates of bacteria found were isolated and tested its characteristics. In the EOPB MOL solutions under aerobic condition, the numbers of bacterial population obtained at each sampling time were different. The highest number of isolates was $197.96 \times 10^{12}$ in the 18 days after the EOPB MOL solutions was made (HSP) and the lowest was $0.02 \times 10^{12}$ at $15 \mathrm{HSP}$. Form of colonies obtained were rounded and irregular with murky white, white, red, yellow, orange, yellowish white, dark yellow, and clear. Most of the bacteria were $71.43 \%$ Gram-positive, $90.48 \%$ fermentative, $75 \%$ negative in softrot, $78.5 \%$ virulent, and $94.05 \%$ negative in hypersensitive test.
\end{abstract}

Keywords: bacterial characteristics, bacterial population, and organic waste.

\begin{abstract}
Abstrak. Luas perkebunan kelapa sawit di Provinsi Lampung termasuk dalam peringkat ke-13 di Indonesia. Tandan kosong kelapa sawit (TKKS) merupakan limbah organik dari tandan buah segar. Jumlah TKKS yang dihasilkan sangat melimpah namun belum dimanfaatkan secara optimal. Penelitian ini bertujuan untuk mengetahui efektivitas larutan mikroorganisme lokal (MOL) dari TKKS secara aerob khususnya untuk mempelajari populasi dan karakteristik bakteri yang terdapat di dalam MOL TKKS. Pengamatan dilakukan dengan menghitung jumlah populasi dan dibedakan berdasarkan bentuk dan warnanya. Selain itu dilakukan juga uji karakteristik lainnya berupa uji gram, uji oksidatif fermentatif (O/F), uji soft rot, uji hipovirulen, dan uji hipersensitif. Hasil penelitian menunjukkan bahwa terdapat 84 isolat bakteri yang berhasil diisolasi dan diuji karakteristiknya. Larutan MOL TKKS secara aerob, jumlah populasi yang didapatkan pada setiap waktu pengambilan sampel berbeda. Jumlah isolat terbanyak $197,96 \times 10^{12}$ pada 18 hari setelah pembuatan larutan MOL (HSP) dan terendah $0,02 \times 10^{12}$ pada 15 HSP. Bentuk koloni yang didapatkan bulat dan tidak beraturan dengan warna putih, putih keruh, merah, kuning, orange, putih kekuningan, kuning pekat, hingga bening. Sebagian besar bakteri $71,43 \%$ bersifat gram positif, $90,48 \%$ bersifat fermentatif, $75 \%$ bersifat negatif softrot, $78,57 \%$ bersifat virulen, dan $94,05 \%$ bersifat negatif pada uji hipersensitif.
\end{abstract}

Kata kunci: karakteristik bakteri, limbah organik dan populasi bakteri.

\section{Pendahuluan}

Provinsi Lampung memiliki luas perkebunan kelapa sawit sebesar 224.175 ribu ha atau termasuk peringkat ke-13 di Indonesia pada tahun 2017 [1] dan pada tahun 2018 perkebunan kelapa sawit di Provinsi Lampung sebesar 267,80 ribu sedangkan total luas perkebunan kelapa sawit di Indonesia sebesar 14.327 ribu ha. Produksi yang dihasilkan sebanyak 550,60 ribu ton 
dengan total seluruhnya $40.567,20$ ribu ton di Indonesia [2].

Tandan kosong kelapa sawit (TKKS) merupakan limbah yang dihasilkan oleh perkebunan kelapa sawit dengan jumlah yang melimpah. TKKS yang diperoleh sebesar $22-23 \%$ [3] dan 30-35\% [4] dari tandan buah segar yang dihasilkan. TKKS dapat digunakan sebagai bahan baku kompos dan pupuk organik. Namun, sampai saat ini pemanfaatan TKKS tersebut belum dilakukan secara optimal.

TKKS dapat digunakan sebagai sumber bahan organik untuk pembuatan pupuk organik antara lain karena kandungan unsur hara makro $(\mathrm{N}, \mathrm{P}, \mathrm{K}, \mathrm{Mg}, \mathrm{Ca}$ ) yang terdapat pada TKKS cukup tinggi [5]. Selain itu, TKKS juga dapat digunakan sebagai bahan untuk pembuatan larutan mikroorganisme lokal (MOL). Mikroorganisme tumbuh pada bahan organik dengan nutrisi dan kadar air yang cukup [6]. Sesuai dengan pernyataan Dewanti (2018) [7] bahwa TKKS tersusun atas kadar air, lignin, holoselulosa, selulosa, hemiselulosa, dan zat ekstratif yang dapat digunakan mikroorganisme untuk hidup.

Larutan MOL TKKS diduga mengandung bakteri bermanfaat. MOL merupakan kumpulan mikroorganisme yang dapat dimanfaatkan sebagai dekomposer dalam pembuatan pupuk organic [8]. Larutan MOL merupakan hasil fermentasi dengan bahan dasar yang tersedia seperti sisa sayuran, nasi, keong mas, dan lainnya. Bahan dasar tersebut merupakan sebagai sumber makanan mikroorganisme untuk hidup [9].

Beberapa hasil penelitian menunjukkan bahwa bakteri Bacillus sp. dan Aeromonas hydrophyla terdapat pada larutan MOL berbahan dasar bonggol pisang. bakteri Staphylococcus sp. Terdapat dalam larutan MOL berbahan dasar keong mas, serta bakteri Bacillus sp., Rhizobium sp., dan Pseudomonas putida terdapat dalam larutan MOL berbahan dasar urin kelinci [10]. Sejauh ini, kandungan bakteri yang terdapat pada TKKS belum diketahui sehingga penelitian ini perlu untuk dilakukan dan diharapkan akan diperoleh bakteri yang berguna sebagai dekomposer, pelarut fosfat, pemacu pertumbuhan, maupun agensia pengendali hayati patogen.

Kondisi yang digunakan dalam penelitian ini yaitu secara aerob atau diperlukan adanya oksigen dalam pembuatan larutan MOL dengan menggunakan alat yang dikembangkan oleh Telaumbanuwa et al. (2019) [11]. Penelitian ini bertujuan untuk mempelajari populasi dan karakteristik bakteri yang terkandung dalam larutan MOL berbahan dasar TKKS secara aerob.

\section{Metode Penelitian}

Penelitian ini dilakukan di Laboratorium Bioteknologi dan Laboratorium Teknik Pertanian serta rumah kaca, Fakultas Pertanian, Universitas Lampung dari bulan September 2018 sampai dengan bulan Mei 2019.

\section{Pembuatan Larutan MOL}

Larutan MOL dibuat sesuai metode yang telah dikembangkan oleh Kesumamingwati (2015) yang telah dimodifikasi dengan mencampurkan 2,5 $\mathrm{kg}$ TKKS yang telah dicacah, $0,5 \mathrm{~kg}$ gula merah yang telah dihaluskan, 2,5 liter air cucian beras, dan 2,5 liter air kelapa. Semua bahan dimasukkan kedalam drum alat yang dikembangkan oleh Telaumbanuwa et al. (2019) [11]. 


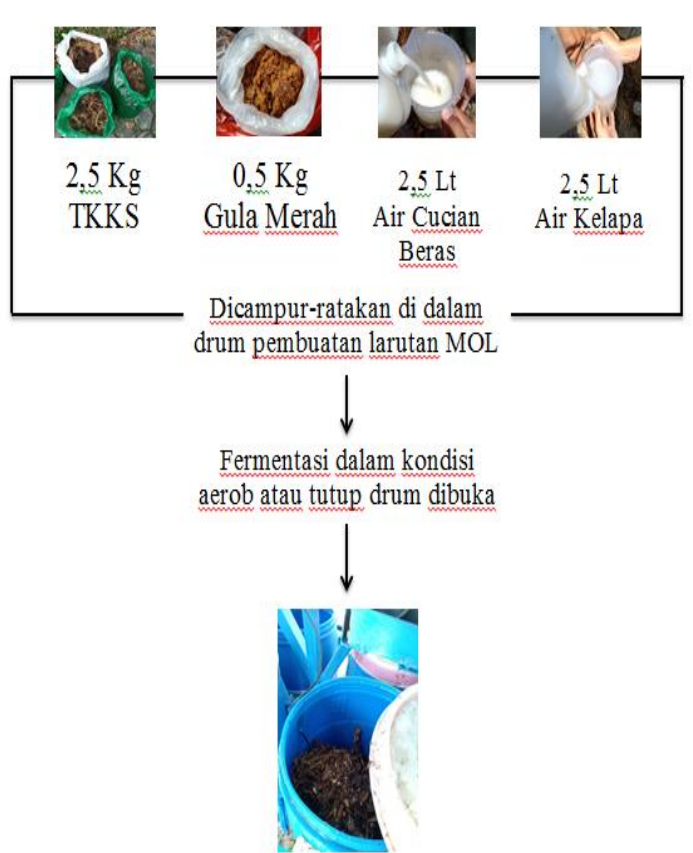

Gambar 1. Proses pembuatan Larutan MOL TKKS secara aerob

Pembuatan larutan MOL dapat disajikan dalam Gambar 1.

\section{Pengambilan Sampel MOL TKKS}

Pengambilan sampel larutan MOL sebanyak $10 \mathrm{~mL}$ dilakukan 9 kali menggunakan botol kaca dengan periode waktu 3 hari. Sampel diencerkan hingga $10^{-8}$ dan $10^{-10}$ dengan jumlah sampel yang diambil sebanyak $50 \mu \mathrm{l}$ dan disebar pada cawan petri yang berisi media Plate Count Agar Peptone (PCAP) dan diamati selama 7 hari.

\section{Populasi Bakteri}

Pengamatan bakteri dilakukan selama 7 hari dengan menghitung jumlah koloni secara komulatif dan membedakan koloni berdasarkan bentuk dan warnanya. Masing-masing koloni ditumbuhkan pada media Yeast Peptone Agar (YPA) lalu diremajakan pada media YPA baru setiap 2 hari sekali.

\section{Karakteristik Bakteri}

Karakteristik bakteri yang ingin diuji meliputi uji gram, uji oksidatif fermentatif (O/F), uji softrot, uji hipovirulen, dan uji hipersensitif. Menurut Anggraini et al. (2016) [12] uji gram dilakukan dengan mencampur adukkan satu ose isolat bakteri dengan $\mathrm{KOH} 3 \%$ dan ditarik perlahan. Jika terbentuk lendir, maka isolat bakteri tersebut bersifat gram negatif.

Uji oksidatif fermentatif (O/F) dilakukan dengan menggunakan 2 tabung reaksi yang berisi media OF. Isolat bakteri ditusukkan kedalam tabung dan salah satu tabung diberi minyak parafin. Perubahan warna diamati dalam 7 hari. Jika perubahan warna hijau ke kuning pada kedua tabung, maka bakteri tersebut bersifat fermentatif dan bersifat oksidatif jika perubahan warna hanya pada tabung reaksi yang tidak diberi minyak paraffin [13].

Uji softrot dilakukan dengan menggoreskan isolat bakteri pada permukaan tengah umbi kentang yang telah dipotong dan direndam dengan air mengalir selama 35 menit. Reaksi positif ditunjukkan dengan pembusukan dan lunak pada permukaan umbi kentang setelah 24-48 jam [14].

Uji hipovirulen menggunakan benih mentimun yang sebelumnya telah direndam etanol $70 \%$ dan larutan $\mathrm{NaOCl} 2 \%$ lalu dibilas dengan air steril. Benih dikecambahkan diatas kertas merang selama 3 hari lalu dipindahkan pada cawan petri berisi media agar air (Water Agar) dengan 3 kecambah tiap cawan petri dan dibuat 3 ulangan. Setelah kecambah berumur 24 jam pada cawan petri, diletakkan isolat 
bakteri yang sebelumnya telah dihomogenkan dengan air steril $1 \mathrm{ml}$ pada bagian hipokotil kecambah. Setelah itu dilakukan pengamatan selama 2 minggu dan dihitung indeks keparahan penyakit (DSI) dengan rumus:

$\mathrm{DSI}=\frac{\sum N}{Z}$

dengan $\mathrm{N}=$ kategori serangan per individu, $\mathbf{Z}=$ jumlah individu yang digunakan.

Indeks keparahan penyakit (DSI) sebagai berikut:

0 = sehat, tanpa bercak pada hipokotil

1 = 1 atau 2 bercak coklat terang dengan ukuran pada kecambah < $0,25 \mathrm{~cm}$

2 = bercak coklat terang (ukuran 0,25$0,5 \mathrm{~cm})$ daerah basah pada kecambah $<10 \%$

3 = bercak coklat terang sampai gelap (ukuran $>1 \mathrm{~cm}$ ) luas daerah basah pada kecambah 10-100\%

4 = kecambah mengalami kelayuan dan kematian [15].

Nilai DSI $<2$ menunjukkan bersifat hipovirulen.

Uji hipersensitif menggunakan daun tembakau dengan menyuntikkan suspensi isolat bakteri yang telah dihomogenkan ke bagian belakang daun, lalu diamati selama 24-48 jam apakah terjadi nekrosis atau tidak. Jika bagian daun yang disuntikkan bereaksi positif, maka bagian daun tersebut mengalami klorosis [16].
Tabel 1. Populasi Bakteri pada larutan MOL TKKS secara aerob

\begin{tabular}{ll}
$\begin{array}{l}\text { Hari Setelah } \\
\text { Pembuatan MOL } \\
\text { (HSP) }\end{array}$ & $\begin{array}{l}\text { Jumlah Populasi } \\
\text { Bakteri yang } \\
\text { didapatkan (CFU/ml) }\end{array}$ \\
\hline 3 & $0,03 \times 10^{12}$ \\
6 & $0,06 \times 10^{12}$ \\
9 & $1,45 \times 10^{12}$ \\
12 & $0,03 \times 10^{12}$ \\
15 & $0,02 \times 10^{12}$ \\
18 & $197,96 \times 10^{12}$ \\
21 & $8,59 \times 10^{12}$ \\
24 & $10,80 \times 10^{12}$ \\
27 & $\infty$ \\
\hline
\end{tabular}

\section{Hasil Dan Pembahasan}

\section{Populasi Bakteri}

Populasi bakteri yang didapatkan dari MOL TKKS disajikan pada Tabel 1.

Pada pengambilan sampel MOL TKKS, 27 HSP tidak dapat dihitung jumlah populasinya dikarenakan bakteri yang tumbuh pada media PCAP menyebar dan menumpuk sehingga tidak dapat dihitung. Hal tersebut tidak sesuai dengan Seni et al. (2013) [17] yang menyatakan bahwa setelah tiga minggu fermentasi akan mengalami penurunan jumlah populasi dikarenakan bakteri yang hidup tidak sebanding dengan bakteri yang mati. Bentuk makroskopis isolat bakteri yang didapatkan yaitu berbentuk bulat dan tidak beraturan. Warna isolat bakteri yang didapatkan yaitu warna putih, bening, putih keruh, kuning, merah, orange, putih kekuningan, kuning pekat, serta bening kekuningan (Gambar 2). 

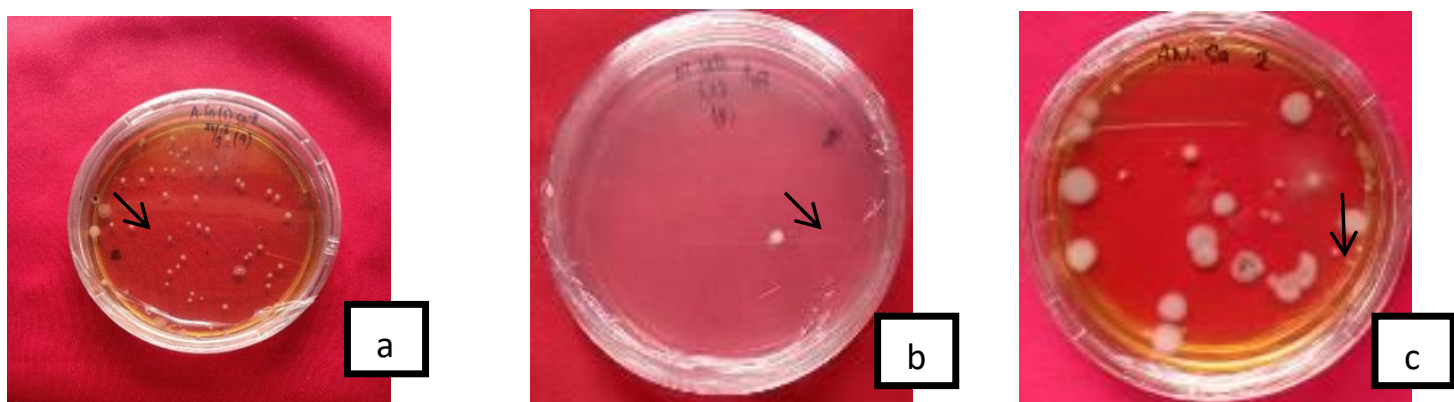

Gambar 2. Isolat bakteri dari larutan MOL tandan kosong kelapa sawit, (a) berwarna kuning dan berbentuk bulat, (b) berwarna putih dan berbentuk bulat, (c) berwarna putih keruh dan berbentuk tidak beraturan.

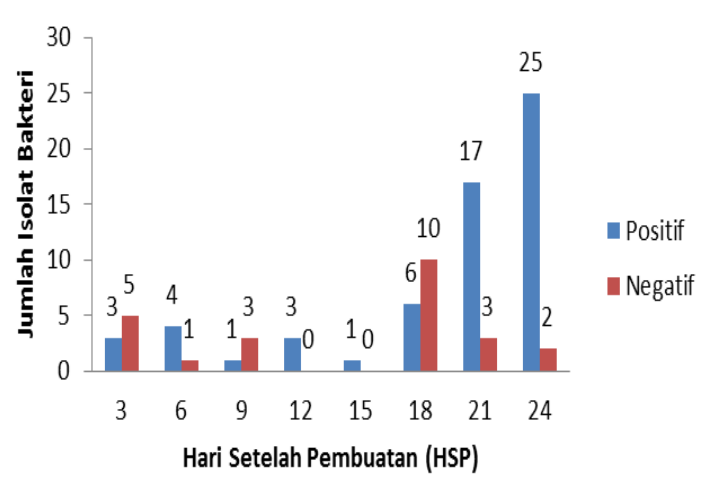

Gambar 3. Uji gram $\mathrm{KOH} 3 \%$ pada larutan MOL TKKS

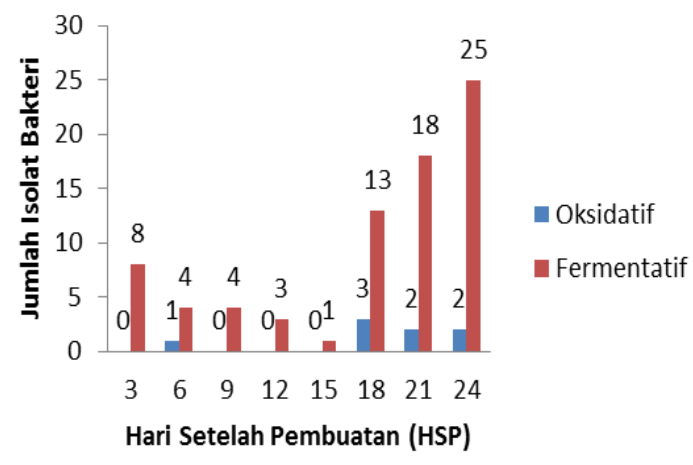

Gambar 4. Uji oksidatif fermentatif (O/F) pada larutan MOL TKKS

Sebanyak 84 isolat bakteri berhasil diisolasi untuk uji lebih lanjut. Uji gram menggunakan $\mathrm{KOH} 3 \%$ didapatkan hasil $60(71,43 \%)$ isolat bakteri bersifat gram positif dan $24(28,42 \%)$ isolat bakteri bersifat gram negatif (Gambar 3). Pengujian menggunakan $\mathrm{KOH}$ berfungsi untuk menyerang lemak dan

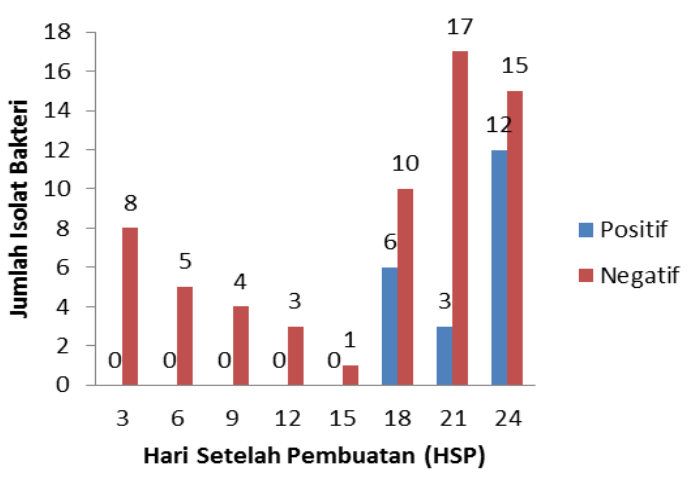

Gambar 5. Uji softrot umbi kentang pada larutan MOL TKKS
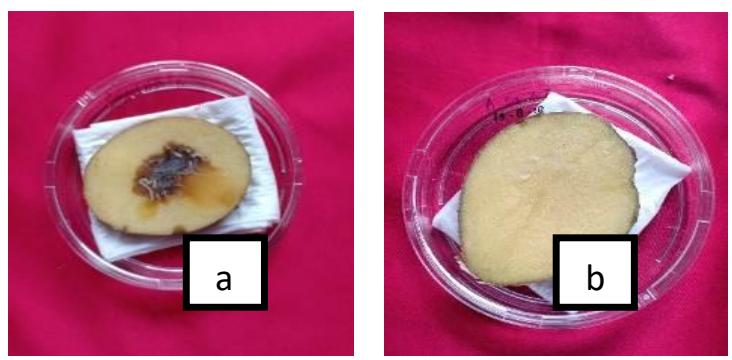

Gambar 6. (a) Reaksi positif pada uji softrot umbi kentang, (b) reaksi negative pada uji softrot umbi kentang

membuat sel bakteri gram negatif pecah [18].

Dari 84 isolat bakteri, didapatkan $76(90,48 \%)$ isolat bakteri bersifat fermentatif dan $8(9,52 \%)$ isolat bakteri bersifat oksidatif (Gambar 4).

Hasil uji softrot 84 isolat bakteri, sebanyak 63 (75\%) isolat bakteri bersifat negatif dan $21(25 \%)$ isolat 
bakteri bersifat positif (Gambar 5). Pada uji softrot, reaksi positif ditunjukkan dengan adanya pembusukaan pada permukaan umbi kentang dan jika ditusuk terasa lunak (Gambar 6). Bakteri yang bersifat softrot positif dapat dikategorikan sebagai bakteri patogen yang menyebabkan penyakit busuk lunak [14].

Kecambah mentimun yang bereaksi positif pada uji hipovirulen ditunjukkan dengan nilai $\mathrm{DSI}<2$ dan virulen $\mathrm{DSI}>2$ (Gambar 7). Dari 84 isolat bakteri yang diuji, terdapat 66 $(78,57 \%)$ isolat bakteri yang bersifat virulen dan $18(21,43 \%)$ isolat bakteri bersifat hipovirulen (Gambar 8). Jika isolat bakteri bersifat hipovirulen, maka kemampuan menginfeksi tanaman rendah dan tidak menimbulkan gejala penyakit. Sedangkan isolat bakteri yang bersifat virulen memiliki kemampuan menginfeksi tanaman yang tinggi sehingga menimbulkan gejala penyakit [15].

Hasil uji hipersensitif pada daun tembakau didapatkan $5(5,95 \%)$ isolat bakteri yang bersifat positif atau menimbulkan gejala klorosis pada bagian daun yang disuntikkan. Daun tembakau yang menunjukkan reaksi negatif terdapat $79(94,05 \%)$ isolat bakteri (Gambar $\mathbf{9}$ ).
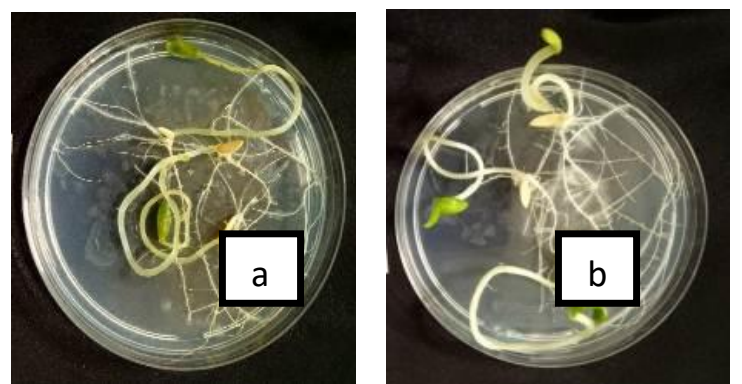

Gambar 7. Reaksi virulen pada kecambah mentimun (a), reaksi hipovirulen pada kecambah mentimun (b) pada larutan MOL TKKS secara aerob

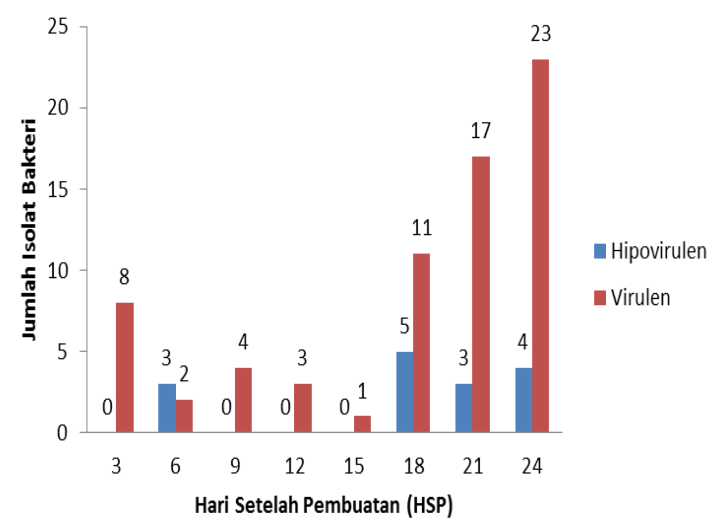

Gambar 8. Uji hipovirulen pada larutan MOL TKKS secara aerob

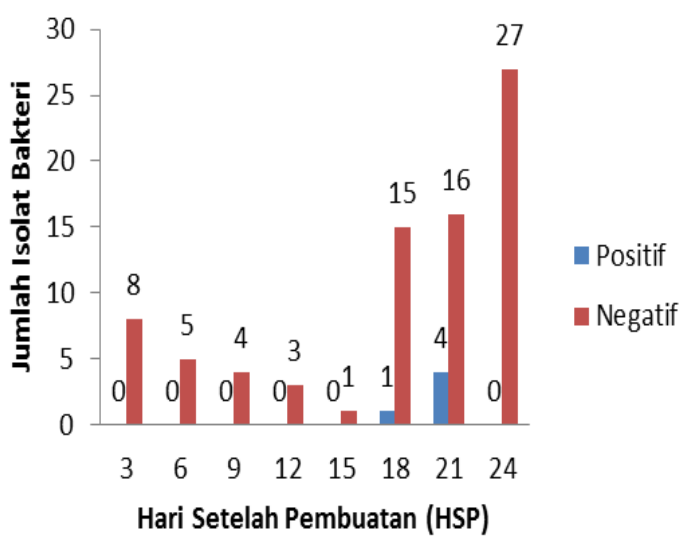

Gambar 9. Uji hipersensitif pada larutan MOL TKKS secara aerob

Pada pengujian hipersensitif tidak semua bakteri patogen tumbuhan bersifat positif [19].

\section{Kesimpulan}

Dari hasil penelitian dapat disimpulkan bahwa jumlah populasi bakteri dari larutan MOL TKKS secara aerob yang didapatkan pada setiap pengambilan sampel berbeda. Jumlah isolat terbanyak $197,96 \times 10^{12}$ pada 18 HSP dan terendah $0,02 \times 10^{12}$ pada 15 HSP. Bentuk koloni yang didapatkan bulat dan tidak beraturan dengan warna putih, putih keruh, merah, kuning, orange, putih kekuningan, kuning pekat, hingga bening. Sebagian besar bakteri $71,43 \%$ bersifat gram positif, 
$90,48 \%$ bersifat fermentatif, $75 \%$ bersifat negatif softrot, 78,57 bersifat virulen, dan $94,05 \%$ bersifat negatif pada uji hipersensitif.

\section{Ucapan Terimakasih}

Penelitian ini merupakan sebagian kecil dari penelitian Hibah Profesor yang didanai Universitas Lampung (Unila) tahun 2018. Penulis mengucapkan terimakasih kepada LPPM Unila atas hibah yang telah diberikan dan kepada Fakultas Pertanian Unila atas fasilitas yang telah diberikan.

\section{Daftar Pustaka}

[1] Direktorat Jendral Perkebunan, "Statistik Perkebunan Indonesia 2015-2017 Kelapa Sawit," Kementrian Pertanian, Jakarta, 2017.

[2] Badan Pusat Statistik. 2019. [Online]: https://bps.go.id/

[3] Salmina, "Studi Pemanfaatan Limbah Tandan Kosong Kelapa Sawit Oleh Masyarakat Di Jorong Koto Sawah Nagari Ujung Gading Kecamatan Lembah Melintang," J. Spasial, vol. 3, no. 2, pp. 3340, 2016.

[4] E. Hambali, Teknologi Bioindustri. Jakarta: Agromedia, 2007.

[5] M. Hatta, Jafri, and D. Permana, "Pemanfaatan Tandan Kosong Sawit Untuk Pupuk Organik Pada Intercropping Kelapa Sawit Dan Jagung," J. Pengkaj. dan Pengemb. Teknol. Pertan., vol. 17, no. 1, pp. 27-35, 2014.

[6] D. W. Amalia and P. Widiyaningrum, "Penggunaan EM4 dan MOL limbah tomat sebagai bioaktivator pada pembuatan kompos," Life Sci., vol. 5, no. 1, pp. 18-24, 2016.

[7] D. P. Dewanti, "Potensi Selulosa Dari Limbah Tandan Kosong Kelapa Sawit Untuk Bahan Baku Bioplastik Ramah Lingkungan," J. Teknol. Lingkung., vol. 19, no. 1, pp. 81-87, 2018.

[8] Juanda, Irfan, and Nurdiana, "Pengaruh Metode Dan Lama Fermentasi Terhadap Mutu MOL (Mikroorganisme Lokal)," J. Floratek, vol. 6, pp. 140-143, 2011.

[9] S. H. Handayani, A. Yunus, and A. Susilowati, "Uji Kualitas Pupuk Organik Cair Dari Berbagai Macam Mikroorganisme Lokal (MOL)," El-Vivo, vol. 3, no. 1, pp. 54-60, 2015.

[10] A. A. Suhastyo, I. Anas, D. A. Santosa, and Y. Lestari, "Studi Mikrobiologi Dan Sifat Kimia Mikroorganisme Lokal (MOL) Yang Digunakan Pada Budidaya Padi Metode SRI (System Of Rice Intensification)," Saintek, vol. 10, no. 2, pp. 29-39, 2013.

[11] M. Telaumbanua, Dermiyati, and R. Suharjo, "Rancang Bangun System Pengaduk Dan Aerator Untuk Pembuatan MOL Secara Otomatis Dari Limbah Kelapa Sawit Dan Nanas Dengan Metode Aerob, Semi Aerob, Anaerob," JTEP, 2019.

[12] R. Anggraini, D. Aliza, and S. Mellisa, "Identifikasi bakteri Aeromonas hydrophila dengan uji mikrobiologi pada ikan lele (Clarias gariepinus) yang dibudidayakan di kecamatan Baitussalam kabupaten Aceh Besar," J. Ilm. Mhs. Kelaut. dan Perikan. Unsyiah, vol. 1, no. 2, pp. 271-286, 2016.

[13] R. Masnilah, A. L. Abadi, T. H. Astono, and L. Q. Aini, 
"Karakterisasi Bakteri Penyebab Penyakit Hawar Daun Edamame Di Jember," Berk. IIm. Pertan., vol. 1, no. 1, pp. 10-14, 2013.

[14] T. Oviana, T. N. Aeny, and J. Prasetyo, "Karakterisasi Penyebab Penyakit Busuk Buah Pada Tanaman Nanas (Ananas Comosus [L.] Merr.)," J. Agrotek, vol. 3, no. 2, pp. 220-225, 2015.

[15] C. Worosuryani, A. Priyatmojo, and A. Wibowo, "Uji Kemampuan Jamur Tanah Yang Diisolasi Dari Lahan Pasir Sebagai PGPF (Plant Growth Promoting Fungi)," J. Agrosains, vol. 19, no. 2, pp. 179-191, 2006.

[16] Zuraidah, "Pengujian Beberapa Bakteri Penghambat Pertumbuhan Xantomonas Oryzae Pv. Oryzae Pada Tanaman Padi.," J. IIm. Pendidik. Biol., vol. 5, no. 1, pp. 18-24, 2013.
[17] I. A. Y. Seni, I. W. D. Atmaja, and N. W. S. Sutari, "Analisis Kualitas Larutan MOL (Mikroorganisme Lokal) Berbasis Daun Gamal (Gliricidia Sepium)," E-Jurnal Agroteknologi Trop., vol. 2, no. 2, pp. 135-144, 2013.

[18] T. J. Chandra and P. S. Mani, "A Study Of 2 Rapid Tests To Differentiate Gram Positive and Gram Negative Aerobic Bacteria," J. Med. Allied Sci., vol. 1, no. 2, pp. 84-85, 2011.

[19] Y. Danaatmadja, S. Subandiyah, T. Joko, and C. U. Sari, "Isolasi Dan Karakterisasi Ralstonia Syzygii," J. Perlindungan Tanam. Indones., vol. 15, no. 1, pp. 7-12, 2009. 